\title{
A TELEVISÃO EXPANDIDA: das especificidades às hibridizações
}

\section{The ex panded television: from specificities to hybridities}

\begin{abstract}
Letícia Capanema
Mestranda em Comunicação e Semiótica pela Pontifícia Universidade Católica de São Paulo. São Paulo, SP - Brasil. E-mail: capanema.leticia@gmail.com
\end{abstract}

\section{Resumo}

Diante da constatação da presença da televisão em outros suportes tecnológicos, que não o aparelho televisivo tradicional - como o computador e os dispositivos moveis - questiona-se haver, nesse contexto, a possibilidade de determinar a especificidade televisiva, já que ela passa a pertencer não mais a um suporte técnico, mas sim a vários. Logo, o estudo propõe trazer a televisão à luz de uma análise teórica, pondo em relevo a questão de sua especificidade num momento de convergência digital e hibridizações tecnológicas e de linguagens. Para tanto, faz-se necessário revisitar teorias que definem e classificam as especificidades televisivas, como as de M. McLuhan, R.Berger e A. Machado, bem como resgatar aquelas que versam sobre conceitos de convergência e hibridização dos meios, como as de R. Bellour e G. Youngblood. Por fim, o estudo pretende investigar os atuais conceitos de pós-televisão de A. Piscitelli, como também as teorias contemporâneas sobre a hibridização dos meios, sejam eles pertencentes à era da cibercultura ou anteriores, como os conceito de remix de L. Manovich e remediation de J. Bolter e R. Grusin.

Palavras-chave: Televisão; Especificidade; Convergência; Hibridização; Pós-televisão.

\begin{abstract}
After verifying the presence of television in others technological supports, which are not the traditional television machine - for instance: computers and mobile devices - we ask, in this context, if it's still possible to define the television specificity, since it belongs to many technological supports and no more to a one. Therefore, this study proposes theoretical analysis of television and its specificity in a moment of digital convergency and hybridizations. For so, its is necessary to revisit theories witch defines and classifies television specificities, like those elaborated by M. McLuhan, R. Berger and A. Machado, and to investigate those that treats of media convergences and hybridization, like the theories of R. Bellour and G. Youngblood. At least, the study aims to investigate the present PostTelevision concept from A. Piscitelli, as well as the contemporary media hybridization theories like the concepts of remix from L. Manovich and remediation from J.Bolter e R. Grusin.
\end{abstract}

Keywords: Television; Specificity; Convergency; Hybridization; Post-television. 


\section{INTRODUÇÃO}

Precedidas pela digitalização da imagem, que trouxe consigo novas questões epistemológicas, a digitalização do sinal de transmissão da televisão e de suas plataformas de exibição despertam outras inquietações que vão ao encontro, principalmente, de questões como a especificidade dos meios. A tualmente, aimagem televisiva não habita somente o aparelho tradicional, tão conhecido de nossos ambientes domésticos. Ela pode também ser identificada em outros suportes tecnológicos, como o computador e os dispositivos móveis. Assim, ao perpassar por várias plataformas, a televisão potencializa seu poder de hibridização, absorve, de forma mais intensa, linguagens e propriedades de outros meios, além de também contaminá-los.

O ciberespaço - entendido como o espaço das comunicações interconectadas por rede de computadores (LEVY, 1999, p. 17) - é o ambiente que abarca as expressões da recente televisão digitalizada. Vale ressaltar que não se trata aqui, exclusivamente, do formato televisivo que se convencionou chamar TV Digital, e sim, dos vários modelos televisivos que possuem seu sinal e sua exibição digitalizados, como, entre outros, a webTV, a mobileTV e a própria TV D igital. D essa maneira, a televisão tradicional que, em geral, distinguia-se dos outros meios de comunicação por ter na sua base um modelo próprio e único, nos planos técnico, econômico, político e de conteúdos, sofre um profundo processo dehibridização, demodo adestilar modelos televisivos variados, de suportes cambiáveis e regidos por lógicas diversas, mas que convergem em um único ponto: são digitais e em rede.

E nesse contexto que se pretende trazer a televisão à luz de uma análise teórica, pondo em relevo a questão desua especificidadenum momento de convergência digital e hibridizações tecnológicas e de linguagens. Para tanto, faz-se necessário, preliminarmente, revisitar teorias que classificam e definem as especificidades televisivas, bem como resgatar aquelas que versam sobre conceitos de convergência e hibridização dos meios, sejam elas pertencentes à era da cibercultura ou anteriores.

\section{Teorias da especificidade televisiva}

Em uma concepção geral, o termo especificidade designa a qualidade daquilo que é próprio, exclusivo, particular de uma espécie. Essa essência das coisas seria, portanto, suficiente para sua identificação e distinção em relação a outras coisas do mundo. Ao pensar a identidade das imagens, Schaeffer (1996, p. 30) afirma que ela "só pode ser captada partindo de sua gênese", ou seja, da forma de produção da imagem e de seu dispositivo gerador. $\mathrm{Na}$ esteira desse raciocínio, a especificidade dos meios de comunicação estaria ontologicamente ligada à sua gênese tecnológica. Entretanto, percebe-se atualmente um movimento de convergência para uma mesma espécie de nascimento técnico dos meios audiovisuais, qual seja o digital, dificultando assim a distinção de cada um deles a partir da gênese tecnológica. Para Arlindo Machado, a especificidade de cada meio consiste naquilo "que o distingue como tal e que nos permite diferenciá-lo dos outros meios e dos outros fatos da cultura humana" (MACHAD O, 2007, p. 59). Nesse sentido, pensar a especificidade da televisão seria identificar-lhe as características essenciais, os aspectos próprios, tecnológicos ou não, que não se fazem presentes em outros meios.

Pode-se dizer que, no período compreendido entre as décadas de 1960 e 1970, os estudos comunicacionais direcionados à televisão são marcados por um olhar que busca a especificidade televisiva e, assim, desenvolve análises através das características próprias desse meio. Tais análises, apocalípticas ou otimistas, fundamentam-se em características peculiares, determinadas por aspectos materiais, econômicos, sociais e culturais da televisão. De fato, naquele período ainda era possível diferenciar os meios de comunicação pelas características exclusivas de cada um, relacionadas, em grande parte, a particularidades técnicas. Assim é que a televisão se distinguia por ser um meio comunicacional gerado a partir de uma tecnologia eletrônica; 0 cinema, fotoquímica; 0 rádio, eletromagnética e os jornais, gerados através do papel. Mesmo a fotografia e as revistas que, respectivamente, possuíam o mesmo suporte técnico do cinema edo jornal, diferenciavam-se por particularidades, como modos e formatos de exibição. A famosa máxima "o meio é a mensagem" formulada em 1964 por Marshal McLuhan, um dos mais notáveis estudiosos da era da especificidade dos meios, expressa enfaticamente a tendência, daquela época, em definir os meios de comunicação por suas especificidades tecnológicas, tendência essa que, mais tarde, seria duramente criticada por reduzir à 
técnica todo o contexto econômico, social, político e cultural dos meios. Raymond Williams, em 1975, atenta para os perigos do determinismo tecnológico: para ele inferências, como as de McLuhan, conferem importância exagerada a detalhes técnicos. É fato que os meios evoluem e se modificam em um contexto muito mais complexo que seus aspectos técnicos. No entanto, não podemos desconsiderar a importância do fator tecnológico, sendo também necessário relacionálo a outras instâncias do contexto, tais como conceitos vigentes, modos deprodução, economias, públicos específicos e práticas expressivas.

McLuhan (1964) não deixa dúvidas quanto ao que acredita ser a especificidade da televisão sua imagem eletrônica e "mosaicada". A partir de tal constatação técnica, o autor canadense desenvolve sua teoria de que a televisão é um "meio frio", na medida em que possui uma imagem de baixa resolução, cuja leitura só se completa com um esforço do telespectador. De fato, a natureza eletrônica da imagem televisiva a distingue de forma clara, por exemplo, do cinema, considerado por McLuhan um "meio quente", por oferecer uma grande quantidade de informação imagética que, ao contrário do que ocorre na televisão, não demanda esforço do espectador para sua leitura. Ademais, a alta definição da imagem fotoquímica possibilita recursos estéticos, como o uso de planos panorâmicos e da profundidade de campo. André Bazin (1958), apesar de tratar propriamente do cinema e não da televisão, reforça a especificidade cinematográfica ao defender que a profundidade de campo é a característica primordial da imagem do cinema, característica essa que permite compor graus variados de densidade dramática através da escala de planos e de movimentos de câmera, como o plano-sequência. Recursos que, no entanto, encontram menoradaptabilidade ao serem aplicados à "achatada" imagem televisiva.

Apesar de a televisão ter absorvido, de certa forma, o filme cinematográfico - um dos repertórios mais assistidos na telinha reticulada -, 0 cinema ainda consegue se manter distinto, como expressão cultural e estética específica. Aspectos como a narrativa veloz, a exploração de cortes, 0 privilégio de planos fechados e uma linguagem mais oral do que visual distinguem a televisão do cinema. Sandy Flitterman-Lewis (apud BO LTER; G RUSIN, 2000, p. 186) expõe as diferenças entre esses meios, do ponto de vista da recepção: o filme no cinema possui uma apreensão coletiva concentrada, proporcionada por um ambiente escuro, uma tela grande e a ausência de interferências externas; de forma contrária, a apreensão do conteúdo televisivo se dá de forma privada, fragmentada e dispersa, uma atenção vacilante e vulnerável a distúrbios externos. Por isso o caráter tão redundante de seu repertório.

Para outros pensadores, como Feuer (apud BOLTER; GRUSIN, 2000, p. 187), a capacidade de ser "ao vivo" é a característica que distingue a televisão e afirma sua superioridade sobre o filme, a fotografia e os meios visuais anteriores a ela. $\mathrm{O}$ filme é sempre distante no tempo, está sempre contando uma história passada, proporcionando uma percepção totalmente diferente do frescor e da urgência do tempo presente televisivo. Assim, como afirma o filósofo Stanley Cavell (apud BOLTER; GRUSIN, 2000, p. 188), "0 paradigma televisual reside na sua capacidade de monitoramento simultâneo", capacidade essa que se torna agora extremamente potencializada no ciberespaço.

A partir da década de 1970, manifestações artísticas passaram a ocorrer fora do circuito oficial da televisão broadcasting, através do uso de vídeo. A princípio, a relação dos artistas com a televisão era eminentemente crítica e paródica. Porém os equipamentos portáteis de vídeo vieram proporcionar a oportunidade de criação de uma linguagem videográfica. Apesar de utilizar os mesmos recursos tecnológicos, e de ser constituído da mesma matéria (a imagem eletrônica), o vídeo ainda se distingue da televisão pela sua metalinguagem crítica. A demais, a partir da mesma década, outras manifestações videográficas e televisivas de naturezas diversas - comerciais, ativistas, governamentais, locais e artísticas surgiram de modo a expandiro conceito detelevisão.

Tendo em vista as concepções televisivas acima citadas, podem ser listadas, em resumo, as características que podem determinar a televisão broadcasting analógica: a imagem eletrônica, o tempo presente, a transmissão monopolizada e unidirecional, seu público de massa, sua recepção privada e fragmentada.

Entretanto, faz-se necessário ressaltar que, sejam quais forem os aspectos que definam a especificidade televisiva, o certo é que eles não são mais exclusivos, de modo que a diferenciação entre os meios já não é tão evidente. Com efeito, seja pela expansão através da emergência de modelos derivados de sua estrutura eletrônica, seja pela 
potencialização da hibridização televisiva através de sua inserção no ciberespaço, o fato é que práticas e expressões próprias do universo da televisão perpassam por outrosmeios, assim como elaadquire tecnologias e modos de funcionamento que antes não lhe pertenciam.

\section{Por uma classificação da videoesfera}

Como já registrado, nas décadas de 1960 e 1970 os estudos de comunicação regiam-se pela tendência em analisar os meios em função de suas especificidades. Mas, a partir de meados da década de 1970, pensadores da televisão começam a perceber eainvestigaralgunsmovimentos deabertura do meio. Cada uma das periodizações que se desenvolvem utiliza um tipo de recorte metodológico, justificado pelo contexto da obra do autor que a produziu. Esses recortes variam entre umavisão tecnológica, econômica, política, semiótica e social. São análises fortuitas, que auxiliam 0 exercício da compreensão das transformações pelas quais vem passando a televisão.

Arlindo Machado (1987) elabora uma distinção entre o que denomina de televisão strico e lato sensu. A primeira, entendida como a televisão tradicional, broadcasting, caracteriza-se pelatransmissão unidirecional - dirigida a um público de massa. É regida por poucas e grandes corporações de telecomunicação ou pelo Estado. A segunda, como uma televisão expandida, corresponde a todas as outras manifestações audiovisuais que encontram no tubo eletrônico seu meio de expressão. Elas compreendem as TVs a cabo, videotexto, TVs comunitárias, "piratas", de livre acesso, a vídeoarte, entre outras. A totalidade dessas manifestações, tanto stricto quanto lato sensu, é denominada, pelo autor, como vídeo. No entanto, a atualidade televisiva ou videográfica vem se mostrando mais complexa, pois caminha para uma expansão ainda maior da TV em seu modo lato, à medida que passa a habitar, também, 0 ciberespaço. As características que distinguem a televisão como stricto sensu, descritas acima, são pulverizadas em formatos de televisão digitalizada e em rede cada vez mais híbridos e diversos.

Na década de 1980, René Berger, em sua obra "The N ew Televison", avalia as manifestações televisivas, que ocorreram de forma tão rápida e com produtos já tão distintos entre si, em seus aspectos técnicos, estéticos, receptivos e políticos.
Assim ele define três campos de experiências televisivas: a macro, a meso e a microtelevisão.

Para Berger (1977), a macrotelevisão corresponde à televisão de massa, chamada de oficial, ou nacional, na Europa, e de livre, ou comercial, nos Estados Unidos e Brasil. É ela caracterizada pelo objetivo deatingiro maiornúmero de espectadores. Sua transmissão se dá através de ondas hertzianas. É centrífuga, unidirecional e hierárquica. Sua programação é mais homogênea, sem grandes inovações. O poder econômico e político de quem a controla se fortalece proporcionalmente ao crescimento da audiência.

A mesotelevisão denomina as televisões locais e por cabo. Caracteriza-se pelo diálogo com um público específico. Os papéis de emissor e receptor são intercambiáveis. Os interlocutores podem estar alternadamente diante da tela ou no ar. Nesse modelo televisivo, o caráter amador semistura ao profissional. A comunicação funciona em uma relação direta com a comunidade a que a TV pertence, sendo, portanto, mais diversa e democrática. Registre-se, porém, que, após a década de 1980, a TV que Berger identifica como TV por Cabo segue outro caminho, que se distância bastante do descrito acima. As TVs locais e regionais continuaram a existir de forma pontual, mas a chamada TV paga, ou por cabo, segue um modelo comercial de televisão que cresceu vigorosamente. É basicamente dedicada ao entretenimento específico, como jogos esportivos, canais de música, de seriados, pornográficos, etc. Sua transmissão por cabos terrestres é paga mensalmente pelo usuário, que não participa da produção do conteúdo veiculado, sua participação se restringe à compra de pacotes de canais, de acordo com suas preferências.

Por fim, a microtelevisão de Berger surge amparada por equipamentos e meios de produção audiovisual portáteis e relativamente baratos. É produzida por pequenos grupos qualitativos, reunidos por interesses comuns, que vão desde atividades militantes a experimentos no campo da videoarte. A relação existente nessa TV não mais é entre emissor e receptor, tampouco entre interlocutores. A relação aqui se dá entre interoperadores. 0 poder de comunicação, nesse sentido, iguala-se em nível do domínio tecnológico.

Considerando-se as análises feitas por Berger há duas décadas, pode-se inferir que, na fase atual da televisão, os instrumentos deprodução audiovisual estão acessíveis como nunca estiveram 
antes, tanto pelo aspecto econômico, quanto pela portabilidade e manuseio. Além disso, tem-se que a evolução para uma tecnologia digital proporciona maior manipulação da imagem captada, abrindo terreno para a criação de uma linguagem audiovisual ainda mais complexa e híbrida.

Com o olhar sobre os repertórios televisivos esuas modificações, em razão do crescenteprogresso da área tecnológica, Arlindo Machado (1987) distingue, em termos semióticos, três fases da televisão: a primeira, caracterizada pelo "ao vivo", data do início das atividades televisivas, época de poucos recursos de gravação e de custo elevado desses poucos disponíveis. A programação acontece, então, marcadapor aspectos próprios dessacondição: "o improviso, o jogo aleatório, a contaminação do produto com acidentes do acaso, a impossibilidade, enfim, de garantir o perfeito controle e a assepsia significante da mensagem" (MACHAD 0, 1987, p. 109). 0 improviso é o que caracteriza, em termos de linguagem, a primeira fase semiótica da televisão. Nessa fase, os aspectos documental e indicial estão mais evidentes, a imagem não sofre qualquer interferência e recursos, como a edição, são timidamente explorados.

Uma segunda fase se distingue justamente pelo uso de recursos de pré-gravação. Feita inicialmente com o auxilio do cinema e, a partir de 1956, com o videotape, a pré-gravação permite manipular os programas de forma mais sistemática. $\mathrm{O}$ vídeotape é, sem dúvida, um recurso que moldou a fisionomia televisiva. D evido a seu baixo custo, se comparado ao filme cinematográfico, passa a ser extensamente utilizado, permitindo, além da gravação do material televisual, sua edição e distribuição. Os programas adquirem uma linguagem ágil, cheia de cortes, pois "os recursos de pré-gravação e a introdução do princípio de edição eletrônica permitem dar maior consistência ao material bruto captado pela câmera" (MACHAD 0, 1987, p. 109).

Machado caracteriza ainda uma terceira fase "por uma imensa manipulabilidade da imagem televisiva, não apenas no nível da articulação dos planos, através do corte e da montagem, mas, sobretudo no nível interno, na articulação dos elementos visuais dentro do quadro" (MACHAD O , 1987, p. 109). São repertórios típicos dessa fase, os videoclipes, as aberturas de programas, os comerciais processados em computadores. As imagens brutas captadas pela câmera passam a ser modificadas e incrementadas por outras imagens sintetizadas no computador, resultando em um híbrido composto de imagens indiciais e icônicas. A imagem digital revela outra sensibilidade, transforma uma televisão predominantemente figurativa em gráfica, coloca em relevo novos problemas de representação, abala antigas certezas epistemológicas, como a "jurássica" indexicalidade da imagem captada, e exige a reformulação de conceitos. $\mathrm{O}$ autor argumenta que "a digitalização da imagem e sua consequente manipulação transformam substancialmente a própria natureza da televisão e a distinguem cada vez mais de outras tecnologias que também operam com a imagem e 0 som" (MACHAD 0, 1987, p. 110).

A pesar de realmente alterar a natureza televisiva e colocar sua especificidade sob novos parâmetros, a digitalização não mais é capaz de distinguir a televisão de outros meios audiovisuais. Afinal, não somente a televisão, como também 0 cinema, os mapas, as revistas, os jornais, os jogos, as rádios e todo e qualquer meio convergem para o código binário. Consequentemente suas linguagens estão contaminadas por recursos gráficos. É certo que a televisão é a precursora na absorção dos recursos expressivos proporcionados pela digitalização da imagem, talvez por ser uma mídia menos tradicionalista e, portanto, com maior facilidade de incorporar inovações. Mas não é menos certo que, hoje, as imagens de qualquer meio renunciam cada vez mais a seu papel de registro indicial, para cumprir na tela, seja ela qual for, sua função icônica primordial.

Propriedades antes exclusivas de certos meios - como, por exemplo, a profundidade de campo no cinema- são hoje perfeitamente simuladas pela computação gráfica, de forma que se torna difícil distinguir um movimento de câmera, feito por uma lente física, de um mesmo movimento sintetizado. Logo, o papel que o computador assume, em relação às especificidades dos meios, é o de transformar em algoritmos as proezas técnicas particulares de cada meio. Assim virtualizadas, essas técnicas podem ser aplicadas a qualquer imagem, de forma a estender seu uso, explicitar seu controle e formalizar sua quantificação e sua programação. Não é de se espantar, pois, que teorias visionárias, como a do filósofo Vilem Flusser (1985), retornem com força vital para ajudar a compreender a complexidade da imagem contemporânea. 
Analisando a máquina fotografia, Flusser (1985) a define como um símbolo que representa a condensação deprincípios científicos quepermitiram a geração dafoto. Tal visão sobre as imagens técnicas se torna evidente com a emergência da imagem digital que, de forma ainda mais sistematizada, cristaliza os conhecimentos científicos sobre 0 mundo físico em formadeoperaçõescomputacionais passíveis de manipulação.

Por fim há que se acrescentar, com a devida vênia, uma terceira fase àquelas explicitadas por Arlindo Machado (1987). Trata-se da fase caracterizada pela digitalização do sinal de transmissão e exibição da televisão e, também, pelo avanço das tecnologias de dispositivos móveis, da conexão em rede e da hibridização dos meios. Assim é que, além da imagem captada e transformada de forma digital, a televisão possui agora a possibilidade de ser transmitida para outros dispositivos que não 0 aparelho de TV convencional. Assim, presente no ciberespaço, a televisão digitalizada e em rede traz à superfície de nossa cultura outras contradições, revela novas linguagens, novos regimes de interface e recepção, e resgata questões ontológicas como a especificidade dos meios.

\section{A era pós-televisiva}

Outra fase televisiva emerge na superfície da videosfera. Mais uma vez, transformações estruturais perturbam o conceito, já pouco estável, de televisão. As modificações atuais se relacionam diretamente com a digitalização das fases do processo televisivo, da produção à exibição. Autores contemporâneos, na tentativa de compreender esse novo momento, esboçam visões do que seria a fase que se convencionou chamar de pós-televisiva.

A expressão "pós-televisão" surge primeiramente em publicações do teórico argentino Alejandro Piscitelli, em 1998. O estudioso se inspira nas ideias presentes na obra "L ife A fter T elevision" de George Gilder, publicada em 1990. Em seu livro, Gilder levanta a tese de que a televisão tradicional, de grande distribuição e pouca opção, morrerá, pois está rapidamente cedendo lugar às possibilidades, criadas pela internet, de uma miríade de opções e de um poder delegado ao usuário. Entretanto Piscitelli (1998) é menos radical, defendendo a tese de que os meios de comunicação não desaparecem, mas, pelo contrário, potencializam suas possibilidades ao permitir a hibridização com outras tecnologias. A partir de tal pensamento, 0 autor argentino sugere uma era "pós-televisiva", que se seguiria à periodização, há muito apresentada por Umberto Eco, consistente nas eras paleo e neotelevisivas.

Para Piscitelli (1998), a paleotelevisão situa-senosanosiniciais do meio, quando seformam as práticas de assistir e entender a linguagem televisiva. Nessa fase, como já foi dito, as transmissões, de caráter massivo, pertencem ao Estado na Europa, ou a grandes corporações privadas na América. A neotelevisão, período intermediário, caracteriza-se pelo aumento da variedade de canais, devido principalmente à introdução da televisão por assinatura. A prática do zapping $^{1}$ se torna recorrente e acelera o modo de assistir à TV. A segmentação da audiência e uma maior oferta de conteúdos preparam o terreno para o surgimento da pós-televisão.

Jean-Louis Missika(2006) é outro pensador dos meios que reconhece a era pós-televisiva como a morte da televisão tradicional. Em 2006, ele publica "L a Fin de la T elévison". Com um raciocínio próximo ao de Gilder, o autor francês salienta outros aspectos da nova fase, tais como o papel do indivíduo, agora, interlocutor despretensioso: "na neotelevisão, o indivíduo comum podia ter acesso ao "écrã" desde que tivesse vivido algo de extraordinário. A pós-televisão vai abolir estaúltima condição. Não é necessário estar em crise para revelar a sua intimidade; não é necessário ter uma experiência rica para contar; não é necessário ser excluído, vítima ou herói. Basta ser. Como se isto tivesse valor em si." (MISSIKA, 2006, apud PRAD O COELHO, 2006, p. 2).

Missika se refere a fenômenos como os reality shows, gênero tão assistido e que já perpassa por várias plataformas como o aparelho de TV, a internet e o celular. Certamente refere-se também ao sucesso do YouTube - um formato de site televisivo que a tudo aceita, com exceção da pornografia, e que se transformou em um depósito de produtos audiovisuais de toda espécie, desde programas antigos de televisão a recém estreados,

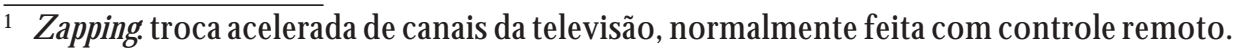


inéditos, videoclipes e uma grande número de vídeos caseiros e produções autônomas. A audiência do Y ouT ube é regida por "febres virais", nas quais conteúdos ganham destaque e proliferam, através da recomendação de seus links feita por meio da própria rede. Disso tudo decorre que aquele indivíduo, que antes se encontrava mimetizado à massa (culturas de massa) e posteriormente aos grupos segmentados (culturas das mídias), emerge, pela primeira vez, na póstelevisão, em sua individualidade. Seu papel passa a ser exercido de forma personificada, na fronteira entre 0 amador e 0 profissional, e, desse modo, as novas mídias passam a se relacionar com ele.

O utras transformações relevantes operam através de adaptações que ocorrem em relação à nomenclatura do universo televisivo. 0 sujeito passa a ser chamado de interator (MACHADO, 2007b, p. 144) e não mais de espectador. Essa pequena mudança já diz muito sobre o papel que 0 indivíduo passa a exercer em sua relação com as novas manifestações de televisão. 0 telespectador é aquele que liga 0 aparelho televisivo e assiste à $\mathrm{TV}$, munido de seu controle remoto quelhe permite fazer as operações de ligar/ desligar, mudar de canal e, quando muito, programar a TV para desligar/ ligar sozinha. A palavra interator carrega em si sentidos outros. $\mathrm{O}$ eletrodoméstico que antes era destinado a ser assistido passa a requerer ser explorado de forma mais profunda que um simples zapping entre os canais. Expande-se assim, também sob esse ângulo, o tradicional universo televisivo. As possibilidades destinadas ao interator abrangem decisões que antes ficavam fora de sua alçada: a programação de conteúdo sob demanda, 0 acesso à rede, a postagem de comentários, o envio de conteúdos para terceiros, ou até mesmo o envio de conteúdos pelo próprio interator.

Rui Cádma, português investigador dos meios, conclui que "a pós-televisão afirma-se cada vez mais como uma televisão para públicos mais diversificados, rompendo progressivamente com um modelo cristalizado de programação, que a televisão tradicional construiu ao longo de décadas e do qual ainda não se separou. A radicação de um novo modelo, que eventualmente soì poderaì ganhar consistência em pleno desenvolvimento da era digital, assentaraì assim prioritariamente numa nova lógica marcadapornovas competências dos públicos face aos programadores. E a ruptura do modelo analógico é como que uma oportunidade histórica para que isso possa acontecer." (CÁD MA, 2001, p. 8). Sem dúvida, a televisão tradicional confrontase agora com seus híbridos interativos, pelo que a convergência digital e para a rede abre terreno a um novo modelo de comunicação audiovisual.

0 fato é que temos um modelo televisivo ainda predominante - a televisão massiva - que habita a videosfera junto a outros modelos, como a televisão por assinatura e as novas mídias. Essa realidade abre espaço para outra espécie de televisão - um modelo híbrido e de transmissão digital, denominado por autores mais radicais de póstelevisão. Portanto, a era pós-televisiva nos revela mais um período de adaptações das práticas, linguagens e plataformas audiovisuais do que propriamente o fim da televisão, como profetizam Gilder e Missika.

\section{Teorias da convergência}

Um dos primeiros pensadores a elaborar um conceito de convergência dos meios é Gene Y oungblood, queem 1970 escrevesuaobraE x panded Cinema. Para ele o cinema é entendido em um sentido amplo, seguindo ipsis literis a tradução de sua nomenclatura - escrita do movimento. $\mathrm{Na}$ esteira desse raciocínio, toda forma de imagem em movimento se enquadra na categoria de cinema, desde as formas de pré-cinemas, como a lanterna mágica, até a televisão, os games, etc. Y oungblood (1970) segue uma linha que trabalha a convergência como um movimento em que um meio, no caso o cinema, abrange todos os outros, assegurando sobretudo sua hegemonia. Tal linha de interpretação das interseções entre os meios possui outros seguidores que, como Youngblood (1970), elegem certas manifestações artísticas como completas e capazes de reunir nelas todas as outras. Richard Wagner, ${ }^{2}$ no princípio do século XIX, defende a ópera como arte completa que abarca todas as outras existentes à sua época - a música, o teatro, a arquitetura, a pintura, a dança. Sergei Eisenstein, ${ }^{3}$ por sua vez, eleva o cinema como arte capaz de englobar a ópera, a música, a pintura, enfim, todas

\footnotetext{
Wilhelm Richar Wagner - 1813-1883: compositor, maestro, teórico musical e poeta alemão.

Sergei Eisenstein - 1848-1948: considerado o mais importante cineasta soviético.
} 
as expressões artísticas de sua época. Por fim, Peter G reenway ${ }^{4}$ defende a televisão como o meio para 0 qual convergem todas as artes citadas por seus antecessores - a ópera, o cinema, o rádio, a música, o teatro eassim por diante. 0 s exemplos supracitados são modos de se assegurar a hegemonia de certos meios, diante da hibridização dos mesmos, através da expansão de suas definições. É muito difícil, porém, manter tais definições por um longo período de tempo. Como mostra a história, o movimento de diferentes doses de um meio em outro é cada vez mais cambiável e constante, sem aparente perspectiva de consolidação.

Talvez um pensamento mais apropriado acerca da interseção entre os meios, atualmente, seja a proposta de Raymond Bellour (1997). O autor acredita na impossibilidade de se pensar os meios de comunicação de forma separada, e propõe analisá-los através do que chama de "passagens" entre as imagens, ou seja, daquilo que, de um meio, está presente em outro. $\mathrm{O}$ que Bellour pratica em seu livro E ntre Imagens é uma nova metodologia de análise, em que as especificidades dos meios são postas de lado e as características que transitam entre os meios, de forma tão fluida, são postas em relevo. Para esse autor, precisar o que é a televisão étarefa difícil, jáquenela transitam todas as imagens, inclusive as do cinema. A imagem eletrônica tudo aceita e, o que é melhor, simultaneamente e ao vivo. D a mesma forma que o filme, a televisão precisa se adaptar à lógica digital para sobreviver. Entretanto, ela possui uma vantagem sobre o cinema, pois sempre absorveu livremente diversas imagens e linguagens de outros meios. Com efeito, a televisão era híbrida e hipermediada mesmo antes do advento da tecnologia digital. E essa, quando surgiu, foi recebida com entusiasmo e abertura. 0 mesmo parece acontecer com as novas possibilidades de transmissão e exibição digitalizada.

\section{0 riginais de segunda geração}

Para Jay Bolter e Richard Grusin (2000), convergência é outra denominação para 0 que chamam de remediation ${ }^{5}$ e acontece de forma mútua, através da hibridização de pelo menos três importantes tecnologias de comunicação: o telefone, a televisão e o computador. Muitas vezes entendida erroneamente como solução única, ou como superposição de uma tecnologia sobre outra, a convergência é, na verdade, promotora da diversidade, multiplicando as possibilidades de formatos dos meios. A ecologia midiática é regida, assim, pela reformulação dos meios pelos meios, como forma de metalinguagem midiática. Tal movimento gera produtos da cultura que funcionam como originais de segunda geração, já que são derivados deformatos anteriorese, ao mesmo tempo, são inéditos. A lógica da eliminação de um meio antigo por um novo não procede. Afinal, segundo a equação dos autores, a re-mediação ou convergência, que gera uma nova tecnologia, deixa pelo menos duas outras disponíveis para o uso cultural.

Fundamentados em seus conceitos ambivalentes - immediacy e hypermediacy ${ }^{6}$-, Jay Bolter e Richard Grusin (2000, p. 31), entendem que, apesar de extremamente hipermediada, opaca, a televisão ainda possui, como força vital, seu caráter de realidade mediada. Como efetivamente podemos ver em alguns programas jornalísticos presentes na televisão - como os que fazem uso de gráficos, letterings e ícones para complementar a imagem do repórter - asintervenções de recursos gráficos digitais na imagem televisiva não são percebidas como distúrbio à autenticidade da realidade, muitas vezes transmitida em tempo presente. Na mesma linha de raciocínio, o teórico Erkki Huhtamo (HUHTAMO apud BOLTER; GRUSIN, 2000, p. 42) afirma que não há mais de se fazer esforço para que os meios pareçam transparentes, simplesmente porque a opacidade não é percebida como contrária à autenticidade da realidade mediada.

\footnotetext{
4 Peter G reenway - nascido em 1942: cineasta galês; famoso e polêmico diretor de cinema

5 Por Remediation entende-se a reformulação de um meio por outro.

6 Immediacy e hypermediacy são conceitos desenvolvidos pelos autores no livro BO LTER, J. D avis; G RUSIN, R. Remediation: understanding new media. Cambridge: MIT Press, 2000. Immediacy se refere à lógica da "transparência”, ou seja, o uso das técnicas expressivas pelos meios com o objetivo de torná-las imperceptíveis. Hypermediacy se refere à lógica oposta, isto é, 0 uso explícito de ferramentas expressivas para mediar de forma "opaca" a realidade.
} 
Com pensamento semelhante, Manovich (2007a), em seu artigo Understanding $\mathrm{H}$ ybrid M edia, faz uma leitura da história recente das imagens em movimento, salientando que, na segunda metade da década de 1990, ocorre uma transformação fundamental: as imagens em movimento, que previamente eram consideradas pertencentes a meios separados e específicos, começam a se combinar de formas variadas. Essa combinação é classificada pelo autor em duas categorias "remixagem" ehibridização.A primeira corresponde à combinação de conteúdos de um mesmo meio, como é o caso do remix na música, expressão cultural em que a palavra foi primeiramente usada. A segunda designa a mistura de conteúdos de meios diferentes, sendo atualmente a mais comum em nossa cultura e a que acarreta transformações mais profundas. Essa segunda categoria, 0 autor denomina de deep remix ability, entendendo-se como tal o fato de que hoje se "remixa" não somente 0 conteúdo de diferentes meios, mas também suas técnicas, métodos e formas de expressão mais fundamentais. Segundo o autor (2001), unidas por um mesmo suporte tecnológico digital, as imagens emergem em uma nova forma de "metameio" e começam a interagir de uma forma que era inimaginável anteriormente. A metalinguagem, portanto, passa a ser uma das novas ló gicas que rege a ecologia dos meios. Q ualquer trabalho produzido através desse novo "metameio" pode usufruir de todas as técnicas e formas de expressão que antes pertenciam a um meio específico, com resultados bem mais complexos que uma simples mistura de conteúdos de um mesmo meio. A televisão, dessa forma, pulveriza-se em vários formatos híbridos ou "metameios", produtos da mistura, basicamente, do computador, da internet, do telefone móvel e da própria televisão.

\section{A crise das identidades midiáticas}

A metáfora dos líquidos, brilhantemente explorada por Bauman (2001) e Novac ([1991] 1993), é uma das mais eficazes para representar a ecologia contemporânea dos meios decomunicação. A fluidez, as misturas, 0 anamorfismo com que os meios se organizam denunciam a perda da "estabilidade que a força de gravidade dos suportes fixos lhe emprestava" (SANTAELLA, 2007, p. 24). A incessante mutabilidade tecnológica impede a formação de "núcleos duros", que antes diferenciavam os meios, e pressupõe uma nova lógica de identificação.

Manovich (2007b) acentua o rompimento do vínculo, antes intrínseco, da mídia com seu suporte tecnológico, ao evidenciar a crise do meio em seu artigo Post-media A esthetics de 2007. Segundo 0 autor, as novas formas midiáticas que habitam 0 ciberespaço não são exatamente meios de comunicação, em seu sentido tradicional. 0 conceito de meio usado pela estética tradicional é fundamentado, eminentemente, por seu caráter material. Porém, no requisito constituição técnica, as novas mídias se misturam por serem todas da mesma natureza - a digital. Outras questões, portanto, entram em cena, para tentar estabelecer a distinção entreosmeios, como aspectos econômicos, sociais e culturais. $\mathrm{O}$ digital, ademais, introduz 0 caráter multimídia, ou seja, a capacidade de corporificação de um mesmo projeto em diferentes formatos. Assim, o tradicional elo entre aidentidade de um objeto midiático e seu meio material se perde. Manovich (2007b) sugere, portanto, outros conceitos que seriam mais adequados à era da cultura pós-digital. 0 autor propõe, então, abandonar o vínculo ontológico dos meios com suas propriedades físicas e aderir conceitualmente à ideia de software, ou seja, aos tipos de operações informacionais que o meio permite ao usuário.

Por fim, uma nova ecologia dos meios faz-se necessária, para compreender-se a forma pela qual as novas mídias se comportam e se distinguem (ou não) entre si. A televisão se insere nesse cenário como um meio, símbolo de uma cultura de massa, que se expande de forma radical ao adentrar o ciberespaço. Tal expansão se dá de tal forma a evidenciar a crise das identidades midiáticas, a ponto de indagarmo-nos sobre o que é televisão hoje. Para responder a tal indagação, talvez devamos seguir o conselho de Manovich: abandonar antigas categorias e estabelecer novas, derivadas da lógica computacional, para assim visualizar a topologia dos novos meios.

\section{REFERÊNCIAS}

BAUMAN, Z. Modernidade líquida. Rio de Janeiro: Zahar, 2001.

BAZIN, A. Qu'est-ce que le cinema? Paris: Les Editions du Cerf, 1958. 
BELLOUR, R. Entre imagens. São Paulo: Papirus, 1997.

BERGER, R. Vídeo and the restructuring of myth. In: BERGER, R. The new televison, Cambridge: The MIT Press, 1977. p. 279-293.

BOLTER, J. Davis; GRUSIN, R. Remediation: understanding new media. Cambridge: MIT Press, 2000.

CÁD MA, F. R. Proto e pós-televisão. Adorno, Bordieu e os outros - ou na pista da "qualimetria". 2001. D isponível em: $<$ http:/ / tinyurl.com/ d59kwt>. Acesso em: 15 mar. 2008.

FLUSSER, V. Filosofia da caixa preta. São Paulo: Hucitec, 1985.

G ILDER, G. Life after televison. New York: Companys, 1990.

GOMBRICH, E. Art and illusion: a study in the psychology of pictoral representation. New York: Princeton University Press, 1960.

LÉ VY, Pierre. Cibercultura. São Paulo: Editora 34, 1999.

MACHAD O, A. A arte do vídeo. São Paulo: Brasiliense, 1987.

Arte e mídia. Rio de Janeiro: Jorge Zahar, 2007a.

O sujeito no ciberespaço: modos de enunciação no cinema e no ciberespaço. São Paulo: Paulus, 2007b.

MANOVICH, L. The language of new media. Massachusett: MIT Press Cambridge, 2001.

.Understanding hybrid media. 2007a. D isponível em: <http:/ / manovich.net>. Acesso em: 10 jan. 2008.

Post-media Aesthetics. 2007b. Disponivel em: <http:/ / manovich.net>. Acesso em: 15 abr. 2008.

McLUHAN, M. Os meios de comunicação como extensões do homem. São Paulo: Cultrix, 1964.

MISSIKA, J-L. La fin de la telévison. In: MISSIKA, J-L. La république des idées. Paris: Seuil, 2006. p. 102-108.
NOVAC, M. A rquiteturas líquidas em el ciberespacio. In: BENEDIKT, M. (Ed.). Ciberespacio los primieros pasos. Méxixo: Conacyt/ Sirius Mexicana, [1991] 1993. p. 207-234.

PRAD O COELHO, M. Para onde vai a televisão? Público. PT, Portugal, 29 set. 2006. Caderno P2. D isponível em: < http:/ / tinyurl.com/ bumlss>. Acesso em: 17 jan. 2008.

PISCITELLI, A. Post/ televisión: ecologia de los médios en la era de internet. Buenos Aires: Paidós, 1998.

SANTAELLA, L. Linguagens liquidas na era da mobilidade. São Paulo: Paulus, 2007.

SCHAEFFER, J-M. A imagem precária: sobre 0 dispositivo fotográfico. Tradução de Eleonora Bottmann. Campinas: Papirus, 1996.

YOUNG BLO OD, G. Expanded cinema. Toronto: Clarke, Irwin \& Company Limited, 1970.

WALTON, $\mathrm{K}$. Mimesis as make-blive: on the foundations of the representational arts. Cambridge: Harvard University Press, 1990.

WILLIAMS, R. Televison: technology and cultural form. Londres: Schocken Books, 1975.

Recebido: $11 / 08 / 2008$

Received: $08 / 11 / 2008$

Aprovado: 03/ 09/2008

A pproved: 09/03/2008 